\title{
Pattern of drugs prescribed for community-residing middle-aged and older adults from the outskirts of Brasília
}

\author{
Otávio de Tolêdo Nóbrega*, Gislane Ferreira Melo, Margô Gomes de Oliveira Karnikowski
}

Curso de Farmácia, Universidade Católica de Brasília

*Correspondence:

O. T. Nóbrega

Curso de Farmácia

Universidade Católica de Brasília - UCB QI 06 conjunto Z casa 09 - Guará 1,

71010-254, Brasília, DF, Brasil

E-mail:nobrega@pos.ucb.br
The objective of this study was to evaluate the medication prescribed for a group of middle-aged and older adults that reside in the outskirts of Brasilia and practice physical exercises regularly at a local University. This analysis considered qualitative and quantitative aspects of the medications prescribed to subjects aged 54 to 81 years-old, including their appropriateness and compliance to the Brazilian essential drug list. The units of analysis consisted in each single medication and each individual subject. Among the one hundred twenty-one individuals interviewed, $19.7 \%$ declared not to take any medicine whereas the remaining $80.3 \%$ revealed to use an average of 3.2 drugs. Among all drugs consumed, 98.1\% consisted of physician prescribed medications, being antihypertensive, anti-inflammatory and analgesic products the most frequent therapeutic classes. Consumption of drugs that should be generally avoided by elderly was found not to vary significantly according to age strata, having nonetheless increased $(P<0.05)$ according to the amount of drugs prescribed. Overall, the group investigated exhibited a homogeneous pattern of drug usage since either the mean general consumption or consumption of particular drug subsets displayed no statistically significant differences related to gender, age, schooling or income. Our findings also indicate a lack of agreement between medications prescribed and the Brazilian cast of essential drugs.
Uniterms

- Elderly

- Middle aged adults

- Drug utilization

- Pharmacoepidemiology

\section{INTRODUCTION}

In Brazil, a remarkable demographic process is taking place, being characterized by an overall increase in estimated life expectancy coupled to a progressive reduction in the fecundity rate, which accounted to a decrease on the youngster/elderly ratio (Chaimowicz,
1997). Data from 1999 points out that the Brazilian contingent of people aged 60 years or older has reached $9 \%$ of the present population, and is estimated to account for 13\% by the year 2020 (IBGE, 2001). Despite the fact that drug consumption is an important issue to all age groups, it is a commonplace that this subject has been more extensively studied among aged individuals, largely 
due to the characteristic structural and functional changes involved in the aging process.

The higher incidence of chronic diseases and degenerative pathologies gives rise to an increased demand for prescription and 'over the counter' medicines to treat these conditions, alleviate pain and provide well-being (Anderson, Kerluke, 1996) rendering older adults susceptible to the risks of polypharmacy and drug-related illnesses. It is remarkable that more than $80 \%$ of the elderly takes a minimum of one medicine a day (Beyth, Shorr, 1999; Laukkanen et al., 1992). In Brazil, similar elevated frequencies of drug use have been observed in metropolitan areas, with a mean utilization ranging from 2 to 5 medications per day, and about one third of all elderly employing more than five drugs simultaneously (Rozenfeld, 2003). Besides that, age related physiological changes influence the pharmacokinetic and pharmacodynamic parameters of several drugs, which can significantly alter cognition, functional capacity and psychomotor ability (Duthie, Katz, 2002).

Even though a regular chronological standard is assumed in developing countries to consider people aged 60 years-old or more as older adults, so that the elderly may constitute a distinct socio-economical branch, it is generally recognized that the accentuated inequities and impoverished conditions typical of these countries worsen the overall health status of all age strata, what may prompt a premature onset of several disorders and disabilities common to the aging process (WHO, 2001). In addition, inadequate prescription and use of improper drugs greatly increase the risk for adverse outcomes, prompting medical attention for the rational use of these products (Nóbrega, Karnikowski, 2004).

Since medication use can be understood as a subset of a country's health service, any health care evaluation effort should necessarily take into account estimates of the suitability and safety of the medication used by and prescribed for its active, community-residing middle-aged and older adults. In this scenario, this study aimed to evaluate the medication prescribed for subjects aged 54 years or over residing in the outskirts of Brasilia, capital of Brazil, by means of an analysis of the pattern of drug consumption, of the appropriateness of the drugs consumed and of the compliance to the Brazilian essential drug list.

\section{METHODS}

This study consisted in a cross-sectional, descriptive analysis of the qualitative and quantitative patterns of medication consumption by a group of middle aged and older adults (men and women) inscribed in a program for physical exercises and medical assistance at a local institution for universitarian education in Brasília. Based on the program's database, a total of $95.3 \%$ $(n=121)$ of the regular practitioners were interviewed between the months of March and May/2002. Briefly, a standardized questionnaire concerning personal data, income and schooling conditions was applied to each subject. Information on the medication consumed in the last 15 days were collected from medicine packages and drug instructions presented by the subjects, and were as follows: brand name or generic denomination of each products, Brazilian standard denomination (abridged as DCB in Portuguese) for each active principle, if prescribed by a medical doctor, if acquired from the public health system (the Unified Health System, abridged as SUS in Portuguese), among other information. For this study, a given medication was only considered as prescribed whenever a written medical prescription was presented.

All industrialized pharmaceutical products and manipulated formulas were included in a database. Homeopathic medicines or any other products that could not have their composition clearly determined, such teas and infusions, were excluded from the database. In order to identify the substances and principles from the brand name of each pharmaceutical product, the Brazilian Dictionary of Pharmaceutical Specialties (abridged as DEF in Portuguese) was employed (JBM, 2002). Active principles presented in each pharmaceutical product were listed and classified according to the AnatomicalTherapeutic-Chemical (ATC) Classification System.

Most drug consumption analyses were performed considering middle-aged and older adults all together, since individuals aged 59 years-old or below supplied grounds for age-related assessments throughout the work. Redundancy was defined as the utilization of more than one medication presenting the same therapeutic purpose (Mosegui et al., 1999). Appropriateness was evaluated according to explicit criteria for identifying medications or medication categories that should generally be avoided by the elderly based on the likelihood of an adverse outcome (Beers, 1997).

This work was approved by the local Ethic Committee and was performed according to guidelines of the Helsinki declaration. Units of analysis on most computations consisted in each single medication and each individual subject. Average drug intake was determined considering only individuals that declared regular use of medication, and not the usual complete roll of respondents encompassing non-users. Statistical analysis performed in this study consisted in a multivariate logistic regression approach, employing the SPSS 10 package program. 


\section{RESULTS}

\section{Socio-economical profile}

Among the 121 participants in this study, 83.5\% $(n=101)$ were women and $16.5 \%(n=20)$ were man. On average, participants aged 65.6 (standard deviation (SD) $=6$ ), ranging from 54 to 81 years-old, being 21 individuals $(17,4 \%)$ aged 59 years-old or less, $33(27,2 \%), 60$ to 64 years-old, 34 (28,1\%), 65 to 69 years-old, 21 (17.4\%), 70 to 74 years-old and 12 individuals $(9.9 \%)$ aged 75 years or older. On what concerns schooling, $20.7 \%$ of all individuals possessed a degree of fundamental educational or higher, whereas the rest possessed either an incomplete basic educational cycle $(60.3 \%)$ or no formal education at all $(19.0 \%)$.

On what concerns monthly family income, $57.8 \%$ declared gains equal to or below three minimum wages (each $=$ US\$ 120.00 at the time of the study), whereas $42.2 \%$ declared gains above three wages. On this matter, it should be highlighted that most individuals (63.6\%) live in families constituted of 3 persons or more, whereas $27.3 \%$ declared living with one more person and only $9.1 \%$ reside alone. On what concerns housing, $85.1 \%$ lived in their own properties, whereas $8.7 \%$ and $6.2 \%$ lived in loaned or rented properties, respectively.

\section{Pattern of drug use}

The one hundred twenty-one subjects interviewed in this study presented packages and drug instructions for a repertoire of 173 distinct pharmaceutical products, that all together totalize 312 medications (items) consumed by the group. Twenty-three participants $(19.7 \%)$ declared not to take any medicine. Among the ninety-eight elder $(80.3 \%$ of the total interviewed) that reported regular use, the amount of medications consumed by each elder varied so that $43.9 \%$ of the users declared taking one single or a maximum of two different medications each day. On the other hand, $42.8 \%$ of all users consumed from three to five different medications, whereas $13.3 \%$ used six or more medications simultaneously. Overall, consumption varied from 1 to 9 different medications/day, what accounted to an average number of $3.2(\mathrm{SD}=2)$ drugs/user. Statistical analysis failed to reveal any quantitative variances in the consumption of medication related to gender, age, schooling or income.

\section{Analysis according to composition}

On what concerns composition, such row of 173 consumed pharmaceutical products could be distributed as follows: $31(17.9 \%)$ generic and $142(82.1 \%)$ brand products. In addition, $146(84.4 \%)$ products were constituted of one single active principle whereas the remaining were fixed-dose associations containing two $(9.8 \%)$, three $(2.9 \%)$ or more $(2.9 \%)$ active principles.

\section{Analysis based on therapeutic and chemical properties}

Among the 312 medications consumed by this group, $98.1 \%(n=306)$ consisted on drugs prescribed by doctors. Among these, antihypertensive medications, antiinflammatory and anti-rheumatic products as well as analgesics and anti-migraine drugs comprised the three most frequently consumed therapeutic classes (Table I).

TABLE I - Consumption pattern of the most frequently prescribed medications according to pharmaceutical classes

\begin{tabular}{lc}
\hline Therapeutic class & Frequency* \\
\hline antihypertensive drugs & $36.5 \%$ \\
anti-inflammatory and anti-rheumatic drugs & $14.7 \%$ \\
analgesics and anti-migraine drugs & $11.8 \%$ \\
psychoactive modulators & $5.2 \%$ \\
pro-digestive/gastrointestinal protective agents & $5.6 \%$ \\
anti-infectious drugs & $2.6 \%$ \\
miorelaxants & $2.6 \%$ \\
cerebral and peripheral vasodilators & $2.2 \%$ \\
\hline
\end{tabular}

* Proportion of medications belonging to one same therapeutic class in relation to the overall repertoire of prescribed medications.

All together, the 173 pharmaceutical specialties were compounded by 114 different active principles. The most frequently consumed chemicals were hydrochlorothiazide (consumed by $32.6 \%$ of the users), acetylsalicylic acid (22.4\%), captopril $(12.2 \%)$, methyldopa $(11.2 \%)$, caffeine $(10.2 \%)$, cinarizin $(10.2 \%)$, metformin $(9.2 \%)$, diclofenac sodium $(9.2 \%)$ and sexual hormone conjugates for postmenopausal replacement therapy (9.2\%).

Considering that antihypertensive drugs were prescribed to $73.5 \%$ of all on-medication individuals, it is important to underline that diuretics were the most frequent therapeutic class, followed by direct vasodilators and antagonists of the angiotensin converting enzyme (ACE inhibitors), among others (Table II).

When the anti-hypertensive consuming group was further analyzed, neither the mean consumption of these drugs (1.2 drugs/user) nor the utilization pattern of any anti-hypertensive subset (not shown) have suffered 
TABLE II - Quantitative distribution of the prescribed antihypertensive medications according to the mechanism of action

\begin{tabular}{lc}
\hline Antihypertensives & Frequency * \\
\hline Diuretics & $40.8 \%$ \\
Direct vasodilators & $37.8 \%$ \\
ACE Inhibitors & $23.4 \%$ \\
$\beta$-Adrenergic blockers & $17.3 \%$ \\
Calcium channel blockers & $16.3 \%$ \\
Central adrenergic blockers & $11.2 \%$ \\
\hline
\end{tabular}

* Proportion of medications possessing the same mechanism of action in relation to the overall repertoire of antihypertensive prescribed medications.

remarkable influence by variables such as age, gender or those socio-economical parameters analyzed, except for an almost five-fold increase in the consumption of ACE inhibitor among the women studied $(\mathrm{P}=0.006)$ when compared to men. In addition, a non statistically significant $(\mathrm{P}=0.63)$, worth mentioning eight fold increase was observed in the mean utilization of cerebral and peripheral vasodilators by women aged 70 to 74 years-old compared to the 60 to 64 years old counterpart.

A similar pattern of consumption poorly influenced by socio-economical variables was also observed for analgesics and non-steroidal anti-inflammatory drugs, except for the fact that elders aged 70 to 74 years-old have proven to use more anti-inflammatory medications in comparison to subsets of individuals aged 54 to 59 and 60 to 64 years old $(\mathrm{P}=0.015)$.

\section{Analysis of the means of obtainment}

When the complete assortment of active principles was compared to the National List of Essential Drugs (abridged as RENAME in Portuguese), it was verified that $72.8 \%$ did not belong to the Brazilian cast of essential pharmaceutical products.

When each of the 312 pharmaceutical items were inquired for their means of obtainment, respondents declared that $38.4 \%$ were provided by the Brazilian SUS, whereas purchase consisted in the mean of obtainment for almost all remaining $(60.0 \%)$ medications, apart from donations which explained the obtainment of $1.6 \%$ of those products.

\section{Inappropriate Pharmacia}

To investigate the therapeutic value of the drugs used, consumption of medications or medication categories whose adverse risks are believed to exceed its health benefits was assessed. According to the most up-to-date criteria (Beers, 1997), twenty-two individuals reported use of one, and one individual reported the use of three improper drugs. It should be highlighted that these criteria were developed for the elderly. Thus, individual aged 59 years-old or less were excluded from this particular analysis. The most frequent types of inappropriate substances used by the elderly were methyldopa and carisoprodol, consumed by 10 and 5 individuals, respectively. Other drugs were diazepam, amitriptyline, hioscin, indomethacin, digoxin and dexchlorpheniramine (Table III).

TABLE III - Absolute events of prescription involving drugs considered inappropriate for consumption by elderly found among the individuals aged 60 years or older

\begin{tabular}{lc}
\hline Drugs & No. of events \\
\hline $\begin{array}{l}\text { Long-acting sedative-hypnotics } \\
\quad \text { Diazepam }\end{array}$ & 2 \\
Muscle relaxants \\
$\quad$ Carisoprodol \\
Antihypertensives \\
$\quad$ Methyldopa \\
Antidepressants \\
$\quad$ Amitriptyline \\
$\begin{array}{l}\text { Antispasmodics } \\
\quad \text { Hioscin }\end{array}$ \\
$\begin{array}{l}\text { Nonsteroidal antiinflammatory drugs } \\
\quad \text { Indomethacin }\end{array}$ \\
$\begin{array}{l}\text { Cardiovascular drugs } \\
\quad \text { Digoxin (dose }>0.125 \text { mg) }\end{array}$ \\
$\quad$ Antihistamines \\
$\quad$ Dexchlorpheniramine & 10 \\
\hline Total & 2 \\
\hline
\end{tabular}

In our conditions, no statistically significant association was devised between consumption of inappropriate drugs and different age, gender, family income or schooling strata. However, the mean consumption of these substances was found to increase significantly according to the amount of drugs prescribed. Elders taking six or more medications have shown a 4.2-fold higher intake $(\mathrm{P}=0.003)$ when compared to the elderly making use of one or two medications, and a 2.4 fold higher intake $(\mathrm{P}=0.029)$ when compared to elders making use of three to five medications.

\section{Redundancies}

Thirteen events of drug association that could be 
considered as redundant use of active principles were found within the entire group studied, predisposing twelve (12.1\%) of the medication consuming individuals to potential hazards from usage of two or more substances with one same therapeutic purpose. Among these, direct cardiovascular dilators were involved in 6 events of redundancy $(46.2 \%)$, antiinflammatory and antirheumatic accounted for 3 $(23.0 \%)$, diuretics for $2(15.4 \%)$, analgesics and antimigraine for $1(7.7 \%)$ and vascular constrictors for $1(7.7 \%)$. Statistical analysis did not reveal variances in the frequency of redundant events according to any variables.

\section{DISCUSSION}

This study describes the pattern of medication consumption among community-dwelling middle-aged and older peoples residing in the outskirts of the Brazilian Federal District. In spite of the efforts to check all products, instructions and prescriptions brought in by the elderly, the methodological approach employed in this study may have revealed an incomplete scenario of the assortment of drugs consumed. Forgetfulness and lack of adhesion are examples of factors that may have contributed to such loss of information. These findings are disquieting since they may underestimate the true prevalence of the inappropriateness and redundancy among prescriptions. In addition, the analysis on appropriateness deliberately did not address the cases of improper use related to drug dosage and duration of therapy or specificities of certain clinical conditions.

Overall, the group exhibited a homogeneous pattern of quantitative consumption since no statistically significant differences could be related to gender, age, schooling or income. The finding that almost all medications consumed $(98.1 \%)$ were prescribed by medical doctors was expected since the low incidence of self-medication reproduces a pattern described elsewhere (Mosegui et al., 1999). Compared to other studies (Pollow et al., 1994; Spore et al., 1997; Rozenfeld, 2003), the mean of prescribed medications consumed by each individual on pharmacological treatment ( 3.2 drugs/user) could be considered rather low. It is unlikely that such result derives from inclusion of middle-aged individual in the study, based on the homogeneous pattern of consumption.

On what concerns typing drug consumption, the remarkable predominance of antihypertensive, antiinflammatory and analgesic drugs over other pharmaceutical specialties greatly resembles the pattern described by Pollow et al. (1994). This predominance of antihypertensive drugs is consistent with the morbidity and mortality profile currently found in Brazil (Chaimowicz,
1997). The observed antihypertensive utilization pattern concurs with trends in the current cardiovascular therapy that prominently base antihypertensive practices on diuretics and ACE inhibitors, and to a lesser extent on $\beta$-adrenergic and calcium channel blockers (Lernfelt et al., 2003). This practice probably derives from studies that show a less significant effect of $\beta$-blockers on primary prevention of coronary disease and total mortality (Ambrosioni et al., 2001) and an elevated incidence of peripheral edema with calcium antagonists (Kostis, 2003) when compared to other antihypertensive approaches such as the use of low-dose diuretic therapy and inhibitors of the angiotensin converting-enzyme.

Besides that, the elevated proportion of participants $(19.7 \%)$ that declared not taking any medicine and the low consumption of either psychoactive medication or drugs related to other chronic disorder (such as diabetes, e.g.) probably highlights a noteworthy feature of this group of physically and mentally active, healthy community-dwelling middle-aged and older-adults. In spite of this scenario, this report shows a worrisome disseminated prevalence of improper and redundant medication among the users, regardless to gender, age or socio-economical status. The number of events involving these drugs was proportional to the pharmacological classes consumed, mostly represented by cardiovascular drugs. In spite of its harmful effects due to causing bradycardia and exacerbating depression, methyldopa alone accounted for the majority of the inappropriate medication found among the drugs prescribed. Almost two thirds of all redundant events involved antihypertensive medications. The fact that all subjects are practitioners of physical exercises probably accounted for the high prevalence of the muscle relaxant carisoprodol, in spite of its potent anticholinergic and sedating properties in the elderly. In addition, three events of redundant use of the antiinflammatories diacerein and diclofenac were observed.

The investigators concluded that improper prescription of drug is common among the communitydwelling elderly in the outskirts of Brasilia and that consumption persists over time, neither ceasing nor decreasing when subjects chronologically shift from middle-aged individuals to the condition of elderly. Actually, our results demonstrate that the more medications are consumed, the more likely are inappropriate drugs to be taken, what indicates that polypharmacy is a risk factor for consumption of improper drugs. In addition, our findings corroborate another phenomenon chronically found in Brazil (Arrais et al., 1997; Mosegui et al., 1999), which consists in the lack of agreement between medications prescribed and the Brazilian cast of essential drugs. 
These results suggest that some factors intrinsic to the Brazilian health system increase the likelihood of receiving improper and costly medication. In first place, these factors may indicate poor quality of the physicianprescribing practices on what concerns the elderly. Secondly, it might be that no other alternatives are available to the population, since drugs such as methyldopa and digoxin are respectively the only central adrenergic blocker and positive inotropic agent available in the Brazilian list of essential drugs. Thirdly, powerful marketing strategies employed by pharmaceutical companies may contribute to an unduly elevated prescription of drugs not truly suitable for the medical status and economical reality of the patient.

In this scenario, discussions and advocacy at governmental instances as well as creation of elderlyspecific health care programs might be of great use in order to bring about alternatives to improve the quality of health practices headed for aged individuals.

\section{RESUMO}

\section{Padrão de medicamentos prescritos para indivíduos de meia-idade e idosos de uma comunidade residente na periferia de Brasília}

O escopo deste estudo consistiu em avaliar a medicação prescrita para um grupo composto por individuos de meia-idade e idosos que reside na periferia de Brasília e pratica exercícios físicos regulares em uma Universidade local. Este estudo considerou aspectos qualitativos e quantitativos das medicações prescritas para individuos com idades entre 54 e 81 anos, incluindo sua adequação e sua concordância com a Relação Nacional de Medicamentos Essenciais (RENAME). As unidades de análise consistiram em cada medicamento e em cada individuo. Entre os cento e vinte e um indivíduos investigados, 19,7\% declararam não fazer uso de medicamento, enquanto os demais $80,3 \%$ revelaram fazer uso de média de 3,2 medicamentos. Entre os medicamentos sendo consumidos, $98,1 \%$ eram prescritos por médicos, sendo anti-hipertensivos, antiinflamatórios e analgésicos as classes terapêuticas mais freqüentes. $O$ consumo de medicamentos que devem ser evitados por idosos não mostrou variar significativamente com a progressão das faixas etárias, tendo, no entanto, exibido aumento marcante $(P<$ $0.05)$ conforme a quantidade de medicamentos prescritos. O grupo investigado exibiu perfil homogeneo de uso de medicamentos, uma vez que tanto o consu- mo geral quanto o consumo de determinados grupos de medicamentos não mostraram variação significativa em função do gênero, faixa etária, grau de escolaridade ou renda. Nossos resultados também sinalizam para a falta de concordância entre os medicamentos prescritos e aqueles pertencentes à RENAME.

Unitermos: Idoso. Pessoas de meia-idade. Uso de medicamentos. Farmacoepidemiologia.

\section{REFERENCES}

AMBROSIONI, E.; BACCHELLI, S; ESPOSTI, D. D; BORGHI, C. Beta-blockage in hypertension and congestive heart failure. J. Cardiovasc. Pharmacol., v. 38 Supl. 3, p. 25-31, 2001.

ANDERSON, G.; KERLUKE, K. Distribution of prescription drug exposures in the elderly: description and implications. J. Clin. Epidemiol., v.49, p.929-935, 1996.

ANDERSON, G.M; BEERS, M.H; KERLUKE, K. Auditing prescription practice using explicit criteria and computerized drug benefit claims data. J. Eval. Clin. Pract., v. 34, p. 283-294, 1997.

ARRAIS, P.S; COELHO, H.L.L; BATISTA, M.C.D.S; CARVALHO, M.L; RIGHI, R.E; ARNAU, J.M. Profile of self-medication in Brazil. Rev. Saúde Pública, v. 37, p. 71-77, 1997.

BEERS, M.H; OUSLANDER, J.G; ROLLINGHER, I.; REUBEN, D.B; BROOKS, J.; Explicit criteria for determining inappropriate medication use in nursing homes. Arch. Intern. Med., v.151, p. 1825-1932, 1991.

BEERS, M.H; Explicit criteria for determining potentially inappropriate medication use by the elderly: an update. Arch. Intern. Med., v.157, p. 1531-1536, 1997.

BEYTH, R.J; SHORR, R.I. Epidemiology of adverse drug reactions in the elderly by drug class. Drugs Aging, v.14, p. 231-239, 1999.

CHAIMOWICZ, F. Health of Brazilian elderly just before of the 21st century: current problems, forecasts and alternatives. Rev. Saúde Pública, v.31, p. 184-200, 1997.

DUTHIE, E.H.; KATZ, P.R. Practice of geriatrics. 3. ed. Philadelphia: WB Saunders Company, 2002. p. 37-46. 
HANLON, J.T.; SCHMADER, K.E.; BOULT, C.; ARTZ, M.B.; GROSS, C.R; FILLENBAUM, G.G.; RUBY, C.M.; GARRARD, J. J. Am. Geriatr. Soc., v.50, p. 2634, 2002.

INSTITUTO BRASILEIRO DE GEOGRAFIA E ESTATÍSTICA- IBGE. Pesquisa Nacional por Amostra de Domicílio - PNAD. Rio de Janeiro, 2001. Disponível em: <http://www1.ibge.gov.br/home/ estatistica/populacao/trabalhoerendimento/pnad99/ sintese/tab1_1_b_1999.shtm.>Acesso em: 22 out. 2003.

JORNAL BRASILEIRO DE MEDICINA - JBM. Dicionário de Especialidades Farmacêuticas: DEF 2002/2003. Rio de Janeiro, 2002. p. 1234.

KOSTIS, J.B. Treatment of hypertension in older patients: an updated look at the role of calcium antagonists. Am. J. Geriatr. Cardiol., v.12, p. 19-27, 2003.

LAUKKANEN, P.; HEIKKINEN, E.; KAUPPINEN, M.; KALLINEN, M. Use of drugs by non-institutionalized urban Finns born in 1904-1923 and the association of drug use with mood and self-rated health. Age Ageing, v.21, p.343-352, 1992.

LERNFELT, B.; SAMUELSSON, O.;SKOOG, I.; LANDAHL, S. Changes in drug treatment in the elderly between 1971 and 2000. Eur. J. Clin. Pharmacol., v. 59, p. 637-644, 2003.

MOSEGUI, G.B.G.; ROZENFELD, S.; VERAS, R.P.;VIANNA, C.M.M. Quality Assessment of drug use in the elderly. Rev. Saúde Pública, v. 33, p. 437-444, 1999.
NÓBREGA, O.T.; KARNIKOWSKI, M.G.O. Medicamentos próprios para idosos. Brasília Médica, v. 40, n. 1/4, p. 36-40, 2004.

POLLOW, R.L.; STOLLER, E.P; FORSTER, L.E.; DUNIHO, T.S. Drug combinations and potential for risk of adverse drug reaction among community-dwelling elderly. Nur. Res., v. 43, p. 44-49, 1994.

ROZENFELD, S. Prevalence, associated factors, and misuse of medication in the elderly: a review. Cad. Saúde Pública, v. 19, p. 717-724, 2003.

SPORE, D.L.; MOR, V.; LARRAT, P; HAWES, C.; HIRIS, $\mathrm{J}$.; Inappropriate drug prescriptions for elderly residents of board and care facilities. Am. J. Public Health, v. 87, p. 404-409, 1997.

STUCK, A.; BEERS, M. H.; STEINER, A.; ARONOW, H.U.; RUBENSTEIN, L.Z.; BECK, J.C. Inappropriate medication use in community-residing older persons. Arch. Intern. Med., v. 154, p.2195-2200, 1994.

WILLCOX, S.M.; HIMMELSTEIN, D.U.; WOOLHANDLER, S. Inappropriate drug prescribing for the community-dwelling elderly. JAMA, v. 272, p. 292296, 1994.

WORLD HEALTH ORGANIZATION - WHO. Health and ageing: a discussion paper. 2001. Disponível em: $<\mathrm{http}$ //www.who.int/hpr/ageing/ageingdiscussion.pdf.. $>$ Acesso em: 15 out. 2003.

Recebido para publicação em 29 de junho de 2004. Aceito para publicação em 16 de junho de 2005. 